山口順 ${ }^{\dagger}{ }^{\dagger}$ 藤城孝 宏 $^{\dagger}$, 正会員 中島真 ${ }^{\dagger}$

\title{
Neural Network for 3-D Shape Identification Using Bright Spots Matrix
}

\author{
Junichi Yamaguchi ${ }^{\dagger}$, Takahiro Fujishiro ${ }^{\dagger}$ and Masato Nakajima ${ }^{\dagger \dagger}$
}

あらまし 視覚センサを用いて物体の 3 次元形状を識別する場合, システムは物体の移動および 回転の影響を受けにくいことが要求される. 筆者らは, 輝点マトリクス投影による空間のコード化 および画像データのパターン変換を用いた効率の良い 3 次元形状識別法を開発した.

\section{1. ま え がき}

視覚センサを用いた物体の 3 次元形状識別において は, 対象物の位置ずれや回転によって生じる画像デー 夕の変化が, 識別アルゴリズムを複雑にするだけでな く，処理時間を増大させるという問題がある.

本稿では, 輝点マトリクス投影により得られる画像 データの周波数空間で極座標変換を施し, 変換データ によって表現される画像のパワースペクトルを用いて 物体の 3 次元形状を効率良く識別する方法を提案す る.

\section{3 次元形状識別法}

ファイバグレイティング視覚センサ (以下, “FG 視 覚センサ”と呼ぶ）は, パターン光投光素子としての ファイバグレイティングを用いて, 物体の置かれる領 域（以下，“観察領域”と呼ぶことにする）に輝点マト リクスを投影し, 空間をコード化することによって距 離デー夕を高速に取得するものである(図 1 1) ${ }^{1)}$. 本 識別法では，まず，輝点投影画像を処理して得られる 輝点移動データ $H(m, n)$, 輝点の 3 次元位置情報を 用いてクラス分けし, さらに 2 値化処理を施すことに よってクラスデータ $f_{c}(m, n)$ を生成する（図 2 は, ク
ラス分けの数が 3 の場合のクラス 2 のデータの表示例 を示す).そして,$f_{c}(m, n)$ にって表現される画像の パワースペクトル

$$
\begin{aligned}
\left|F_{c}(u, v)\right|^{2}= & \mid \frac{1}{M N} \sum_{m=0}^{M-1} \sum_{n=0}^{N-1} f_{c}(m, n) \\
& \left.\cdot \exp \left[-j 2 \pi\left(\frac{m u}{M}+\frac{n v}{N}\right)\right]\right|^{2}
\end{aligned}
$$

(c: class number)

を求め (図 3), さらに $\left|F_{c}\right|^{2}$ につて, 動径 (中央から の距離) を $\rho$, 偏角を $\theta$ として, 極座標変換を行う $(\rho$ - $\theta$ マッピング）(図4)。またさらに，マッピングデー 夕 $M_{c}(\rho, \theta)$ にっって表現される画像のパワースペクト ル

$$
\begin{aligned}
\left|P_{c}(\alpha, \beta)\right|^{2}= & \mid \frac{1}{P \Theta} \sum_{\rho=0}^{P-1} \sum_{\theta=0}^{\Theta-1} M_{c}(\rho, \theta) \\
& \left.\cdot \exp \left[-j 2 \pi\left(\frac{\rho \alpha}{P}+\frac{\theta \beta}{\Theta}\right)\right]\right|^{2}
\end{aligned}
$$

を求める.このようにして得られる $\left|P_{c}\right|^{2}$ は, 入力パ ターン $f_{c}$ が回転を伴う移動をした場合に不変であり, この $\left|P_{c}\right|^{2}$ を用いることによって $f_{c}$ の識別が可能とな る.しかし， 3 次元物体が水平台上で平行移動または 台に垂直な回転軸の周りに回転した場合（以下，単に “移動”, “回転” と呼ぶ), 輝点移動データの変化によ りクラスデータ $f_{c}$ が変化し, $f_{c}$ を演算処理して得ら

キーワード：3 次元形状識別, ファイバグレイティング, ニューラルネットワーク

1991 年 2 月 8 日, テレビジョン学会技報報告, Vol. 15. No. 13 に発表

1991 年 6 月 12 日受付

†慶応義塾大学 理工学部 電気工学科 (广 223 横浜市港北区日吉 3-14-1, TEL 045-563-1141)

$\dagger$ Faculty of Science and Technology, Keio University (3-14-1, Hiyoshi, Kouhoku-ku, Yokohama 223, Japan) 


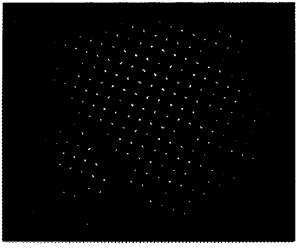

(a)

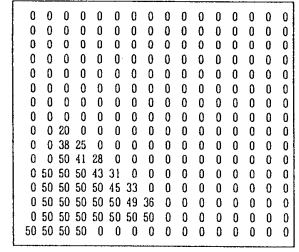

(b)
図 1 FG 視覚センサにより得られる輝点投影画像 (a), および輝点の 3 次元位置検出によって得 られる輝点移動データ $(\mathrm{b})$ の例 $(n$ : 輝点の高 さ $(\mathrm{mm}))$

(a) An example of the spots projection pattern obtained by the FG vision sensor. (b)Spot shift data obtained by the detection of the three dimensional position of the bright spot. $(n$ : height $(\mathrm{mm}))$

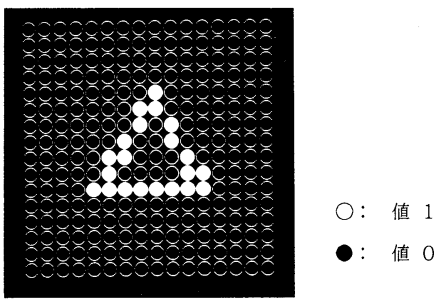

図 2 クラスデータの表示例（観察領域に三角錐を置 いた場合)

An example of the classification data (the triangular pyramid was located in the object area).

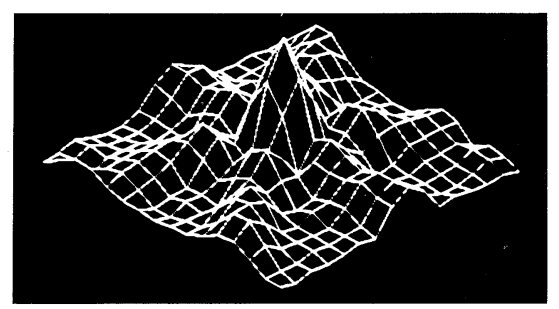

図 $3 f_{c}(m, n)$ のパワースペクトルを求めた結果の表 示例 $\left(f_{c}\right.$ : 図 2 に示されるクラスデータ)

An example of the power spectrum of $f_{c}(m, n) \quad\left(f_{c}\right.$ : classification data shown in fig. 2)

れる $\left|P_{c}\right|^{2}$ が変化する．この場合， $\left|P_{c}\right|^{2}$ の類似度の決 定だけでなく，観察領域内に形状の異なる他の物体を 置いた場合に得られる $\left|P_{c}\right|^{2}$ との判別を一義的に表現 することが困難となる．

そこで本方式では，ニューラルネットワークの学習 能力および般化能力を利用し4), 図 5 に示されるよう に, $\left|P_{c}\right|^{2}$ における $\mathrm{A}$ および $\mathrm{B}$ 領域での值によって示 されるパターンを識別する. 入力層は輝点移動デー夕 のクラス分けの数と同数のユニットグループにより構

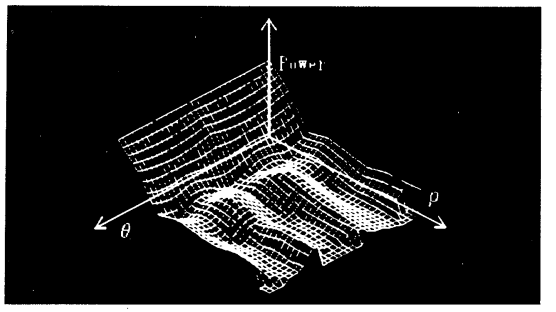

図 4 図 3 に示されるデータについて $\rho$ - $\theta$ マッピン グを行った結果の表示例

Result of $\rho-\theta$ mapping of the data shown in fig. 3 .

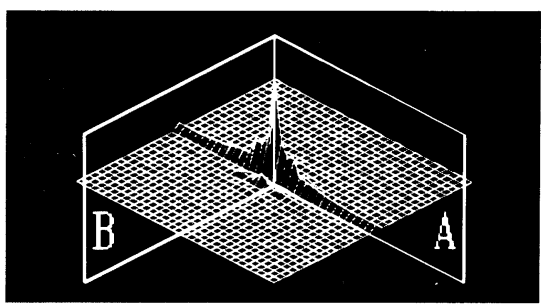

図 5 ニューラルネットワークの入力データ Input data of the neural network.

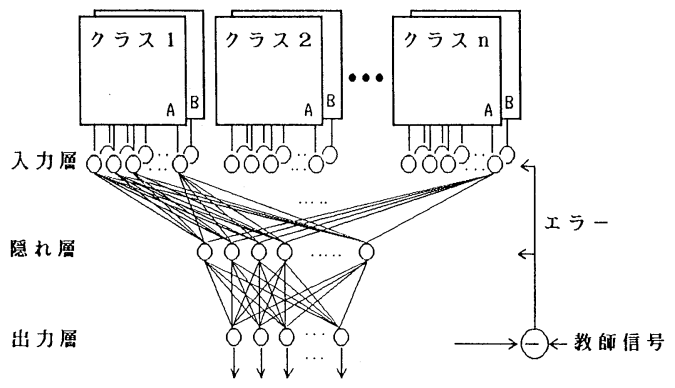

図 6 ニューラルネットワークの構成

Structure of the neural network.

成し, 各グループは $\mathrm{A}$ および $\mathrm{B}$ 領域でのサンプリン グの数と同数の入力ユニットを持つ (図 6). 本識別法 では, 出力ュニットの出力值により $\mathrm{A}$ および $\mathrm{B}$ 領域 での值に対するネットワークの応答が示されることに よって物体の 3 次元形状が識別される.

\section{3. 実験および検討}

被検体 (図 7) を観察領域内の適当な 1 つの位置に適 当な 1 つの回転角度で置き, その際の輝点投影画像 (被検体 1 つにつき 1 枚)を用いてネットワークの学習 を行った後, 観察領域を 9 分割し(等分割した), 被検 体を分割領域の中央で $45^{\circ}$ おき 8 方向に回転させた場 合（この場合に輝点投影画像はすべてが未学習画像） に被検体の形状を識別できるかをテストした。 

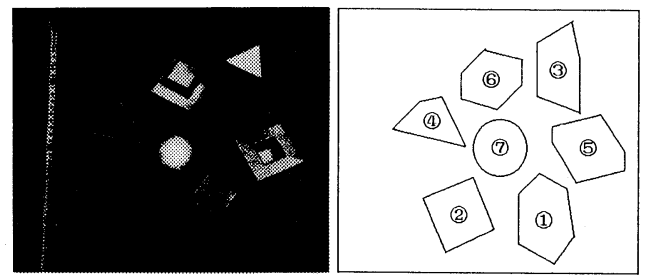

図 7 実験に用いた被検体 Objects used in the experiment.

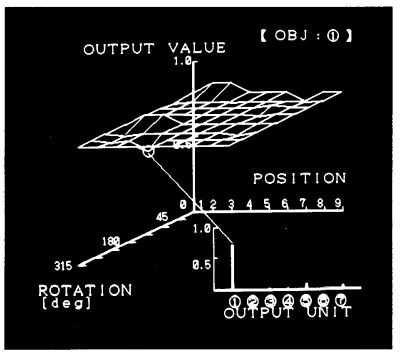

図 8 識別結果の表示例（被検体番号 1 の被検体を用 いた場合）

Result of the identification of the object (object number: 1).

表 1 被検体の識別結果

Results of the identification of the objects.

\begin{tabular}{c|c|c|c|c|c|c|c}
\hline $\begin{array}{c}\text { 出力 } \\
\text { ユニット }\end{array}$ & (1) & (2) & (3) & (4) & (5) & 6) & (7) \\
\hline (1) & 0.721 & 0.000 & 0.013 & 0.015 & 0.086 & 0.007 & 0.056 \\
\hline (2) & 0.000 & 0.738 & 0.015 & 0.065 & 0.034 & 0.007 & 0.044 \\
\hline (3) & 0.109 & 0.120 & 0.790 & 0.000 & 0.027 & 0.005 & 0.020 \\
\hline (4) & 0.005 & 0.011 & 0.013 & 0.649 & 0.010 & 0.048 & 0.050 \\
\hline (5) & 0.152 & 0.036 & 0.090 & 0.006 & 0.633 & 0.006 & 0.006 \\
\hline (6) & 0.001 & 0.154 & 0.054 & 0.194 & 0.002 & 0.631 & 0.005 \\
\hline (7) & 0.029 & 0.011 & 0.014 & 0.172 & 0.163 & 0.048 & 0.731 \\
\hline
\end{tabular}

図 8 は被検体番号 1 の被検体についてテストした結 果の表示例であり, 図中の横軸は 9 分割領域の番号, 斜めの軸は物体の回転角度, 縦軸は出力ユニットの出 力値を示す. 図中の右下に示されるグラフは, 出力值 が最も落ち込んでいる場合のすべての出力ユニットの 出力值である（この場合に，他の出力ユニットの出力
值との差が最も小さくなった)．また，この場合の出 力值をすべての被検体について示したものが表 1 であ る. 実験では, 観察領域内に置かれた被検体に対応す る出力ユニットの出力值が他の出力ュニットの出力值 に比べ充分に大きな值となり，本方式が 3 次元形状識 別のため有効であることが検証された．なお，輝点投 影画像を取り込んでからニューラルネットワークの出 力を得るまでが約 10 秒となった。

\section{4. む す び}

本稿では, 輝点マトリクス投影による空間のコード 化および画像データのパターン変換によって, 物体の 3 次元形状を高速に識別する方法について提案し，実 験システムを用いて行った識別実験の結果について報 告した．本方式を用いることにより，物体が回転を伴 う移動をした場合にも 3 次元形状を効率良く識別する ことができた

\section{〔参 考 文 献〕}

1）中沢，中島，小林：“ファイバグレイティングを用いた 3 次 元形状計測システムの開発”, 信学論 D, J69-D, $12, \mathrm{pp}$. 1929-1935 (Dec. 1986)

2) K. Nakazawa, M. Shimizu, M. Nakajima and S. Yuta: "Measurement of 3-D Shape and Position by Fiber Grating Vision Sensor Installed on Manipulator", Proceedings of the IEEE Workshop on IROS, pp. 611-616 (Nov. 1988)

3）山口, 中沢, 中島：“ファイバグレイティングを用いた実時 間侵入者検知システム”, 電学論 D, 110-D，7， pp. 814820 (July 1990)

4) D. E. Rumelhart, G. E. Histon and R. J. Williams : "Learning Representations by Back Propagating Errors", Nature 323, 535 (1986)

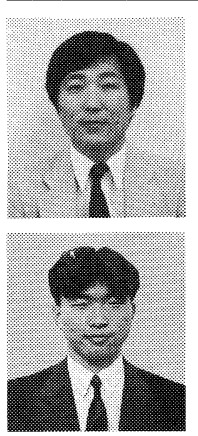

やまぐ 恻いい 気通信・計算機科学卒業. 54 年, 綜合警備保 障(株)に入社. 62 年より, 慶応義塾大学理 工学部へ出向. パターン計測の研究に従事.

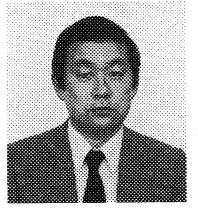

中架心゙島 䈯人 昭和 48 年, 慶応義塾大学大 学院博士課程修了. 56 年, 同大学助教授. 63 年, 同理工学部教授. 画像処理, 超音波 の応用などに関する研究に従事. 工学博士. 正会員. 